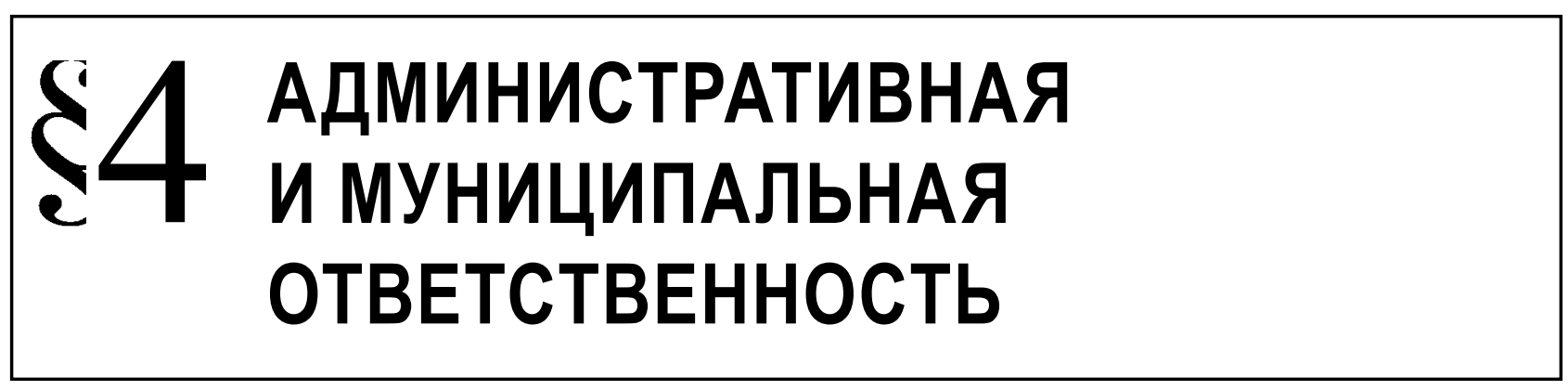

Лапина М.А., Карпухин Д.В.

\title{
КОНСТРУКЦИЯ СОСТАВОВ ПРАВОНАРУШЕНИЙ И МЕРЫ ГОСУДАРСТВЕННОГО ПРИНУЖДЕНИЯ В АДМИНИСТРАТИВНОМ И БЮДЖЕТНОМ ЗАКОНОДАТЕЛЬСТВЕ
}

\begin{abstract}
Аннотация: Развитие административного законодательства привело к формированию самостоятельных отраслей российского законодательства - финансового, налогового, бюджетного, таможенного, в связи с чем, в кодифицированные нормативные акты - Бюджетный кодекс РФ, Налоговый кодекс (часть 1) РФ были введены составы правонарушений, за совершение которых налагались соответствующие санкции. Целью настоящей статьи является сравнительно-правовой анализ норм, устанавливающих юридическую ответственность за совершение правонарушений в бюджетной сфере, содержащихся в КоАП РФ и БК РФ и формулирование конкретных предложений по упорядочиванию мер государственного принуждения, сформулированных в действующем законодательстве. Методологическую основу статьи составили современные достижения теории познания. В процессе исследования применялись общефилософский, теоретический, диалектика, системный метод, анализ, синтез, аналогия, дедукция, наблюдение, моделирование, традиционно правовые методы (формально-логический), а также методы, ис-пользуемые в конкретно-социологических исследованиях (статистические, экспертные оценки и др.). Авторы настоящей статьи полностью разделяют сформировавшуюся в отечественной науке административного права точку зрения на административно-правовую природу бюджетных мер принуждения, которые применяются «финансовыми органами и органами Федерального казначейства (их должностными лицами) на основании уведомления о применении бюджетных мер принуждения органа государственного (муниципального) финансового контроля» (cm. 306.2 ч. 1 БК РФ). В связи с изложенным, представляется актуальным обращение к проблеме соотношений понятий мер административного и бюджетного принуждения. Меры последнего зафиксированы в части 2 статьи 306.2 Бюджетного Кодекса РФ.
\end{abstract}

Ключевые слова: состав, правонарушение, ответственность, принуждение, санкция, пресечение, администрирование, запрет, финансы, объект.

\section{О соотношении понятий «меры} государственного принуждения» и «меры юридического воздействия»

В последние время в отечественной науке административного права активизировался интерес к изучению проблем юридической ответственности в бюджетном праве. Он обусловлен тем, что в действующий Бюджетный кодекс Российской Федерации Федеральным законом от 23 июля 2013 г. № 252 - Ф3 «0 внесении изменений в Бюджетный кодекс Российской Федерации и отдельные законодательные акты Российской Федерации» была введена глава 29 «Общие положения о бюджетных нарушениях и применении бюджетных мер принуждения» и глава 30 «Виды бюджетных нарушений и бюджетные меры принуждения, применяемые за их совершение» ${ }^{1}$.

Авторы настоящей статьи полностью разделяют сформировавшуюся в отечественной науке

\footnotetext{
Федеральный закон от 23 июля 2013 г. № 252 - Ф3 «О внесении изменений в Бюджетный кодекс Российской Федерации и отдельные законодательные акты Российской Федерации» // РГ. N 172. 07.08.2013.
} 
административного права точку зрения на административно-правовую природу бюджетных мер принуждения, которые применяются «финансовыми органами и органами Федерального казначейства (их должностными лицами) на основании уведомления о применении бюджетных мер принуждения органа государственного (муниципального) финансового контроля» (ст. 306.2 ч. 1 БК РФ). В связи с изложенным, представляется актуальным обращение к проблеме соотношений понятий мер административного и бюджетного принуждения. Меры последнего зафиксированы в части 2 статьи 306.2 Бюджетного Кодекса РФ.

Следует отметить, что в науке административного права институт административного принуждения является сформировавшейся понятийной категорией, содержащейся в классических учебниках. Рассмотрим сущность этого института и виды административного принуждения на примере различных точек зрения, содержащихся в учебниках ведущих отечественных административистов Л.Л. Попова, Ю.М. Козлова и Д.Н. Бахраха.

Так, Л.Л. Попов и Ю.И. Мигачёв трактуют административное принуждение как «разновидность государственного принуждения, которому присуще такие общие признаки государственного принуждения, как государственно-властное воздействие и регулирование нормами права. Оно применяется для того, чтобы заставить субъекта совершить те или иные действия или воздержаться от них либо подчиниться установленным ограничениям»².

Д.Н. Бахрах считает, что корректнее использовать понятие не «административное принуждение», а «административно-правовое принуждение», хотя принципиально авторское определение указанного термина не отличается от предыдущей трактовки. «Административно-правовое принуждение, - отмечает учёный, - это особый вид правового принуждения, состоящий в применении субъектами публичной функциональной власти установленных нормами административного права принудительных мер к гражданам и коллективным субъектам административного права в связи с их неправомерными действиями» ${ }^{3}$.

Ю.М. Козлов отмечал, что принуждение является одним из административно-правовых мето-

\footnotetext{
2 Административное право Российской Федерации / отв. редактор Л.Л. Попов. Учебник для бакалавров. М., 2014. С. 202.

3 Бахрах Д.Н. Административное право России. Учебник. 5-е издание. М., 2010. С. 437-438.
}

дов управления и представляет собой «комплекс различных приёмов и способов управляющего воздействия в случаях недолжного поведения управляемых, отклонений от их требований, сформулированных административно-правовыми нормами (в особенности), а по существу, всей системой нормативных правовых актов различной юридической силы». ${ }^{4}$ Административное принуждение практически воплощается в применении мер принудительного воздействия 5 .

Учёный подчеркивал, что меры административного принуждения являются самостоятельными мерами, наряду с мерами уголовными, дисциплинарными и материальными, и выражаются в санкциях правовых норм в виде мер юридической ответственности 6 .

Три вида мер административного принуждения, выделенные классиком административного права Ю.М. Козловым, и в настоящее время общепризнанны в науке административного права: 1) административно-предупредительные меры; 2) административно-пресекательные меры; 3) административно-наказательные меры ${ }^{7}$.

Первые применяются с целью предупреждения (профилактики) негативных явлений в сфере государственного управления, «включая правонарушения, а также возможные вредные последствия такого рода проявлений» ${ }^{8}$. К их числу автор отнёс проверку документов, удостоверяющих личность; досмотр вещей и личный досмотр; контрольные и надзорные проверки и т.д.

Административно-пресекательные меры используются с целью «прекращения в принудительном порядке противоправных деяний и предотвращение их вредных последствий» ${ }^{9}$. Учёный отнёс к их числу требование прекратить противоправное деяние; запрещение эксплуатации транспортных средств, техническое состояние которых не соответствует существующим требованиям и другие ${ }^{10}$.

Наконец, административно-наказательные меры, которые, по мысли Ю.М. Козлова, «имеют специфическое самостоятельное значение и со-

\footnotetext{
4 Козлов Ю.М. Административное право. Учебник. М., 2005. С. 356.

См.: там же.

6 См.: там же.

7 См.: Козлов Ю.М. Административное право. С. 360.

8 Там же.

9 Там же. С. 361.

10 См.: там же.
} 
ставляют содержание административно-правового института «Административная ответственность» и «Административно-деликтное право»» ${ }^{11}$.

Следует отметить, что Д.Н. Бахрах придерживается несколько иной классификации мер административного принуждения. По мысли учёного «административное принуждение осуществляется с целью охраны правопорядка. Но эта цель достигается различными способами: путём предупреждения, пресечения правонарушения, восстановления вреда, причиненного ими, наказания. Поэтому в зависимости от той непосредственной цели, ради которой используются средства административного принуждения, можно различать 1) меры предупреждения, 2) пресечения, 3) наказания и 4) восстановительные меры (например, взыскание в административном порядке незаконно полученного, недоимки, пени ${ }^{12}$.

Л.Л. Попов и Ю.И. Мигачёв выделяют четыре группы мер административного принуждения: 1) административно-предупредительные меры, 2) меры административного пресечения, 3) меры административной ответственности, 4) меры административно-процессуального обеспечения ${ }^{13}$.

Первая группа мер ориентирована на превенцию, то есть имеет ярко выраженную профилактическую направленность. Они в свою очередь подразделяются на четыре категории:

- применяемые в целях предотвращения угрозы наступления возможных вредных последствий (введение карантина);

- направленные на предупреждение правонарушений (проверка документов, таможенный досмотр);

- $\quad$ препятствующие уклонению субъектов от исполнения определённых обязанностей;

- лечебно-предупредительные меры, назначение которых состоит в обеспечение общественной безопасности, оказании медицинской помощи ${ }^{14}$.

Вторая - направлена на немедленное принятие мер уполномоченными субъектами с целью с целью пресечения противоправных действий. К таковым, например, относится административное задержание нарушителя, запрет эксплуатации не-

\footnotetext{
11 Там же. С. 363

12 Бахрах Д.Н. Административное право России. Учебник. 5-е издание. С. 439.

13 См.: Административное право Российской Федерации / отв. редактор Л.Л. Попова С. 203.

14 См.: там же. С. 204.
}

исправных машин и механизмов и т.д. $)^{15}$. «Суть подобных мер, - пишут авторы, - несмотря на их многообразие, состоит в принудительном прекращении противоправных действий (деятельности) граждан, должностных лиц, организаций, нарушающих установленный порядок» ${ }^{16}$.

Под мерами административной ответственности Л.Л. Попов и Ю.И. Мигачёв понимают меры наказания, назначаемые в соответствии с КоАП РФ за совершённые административные правонарушения ${ }^{17}$.

Наконец, меры административно-процессуального обеспечения представляют собой совокупность средств и способов, обеспечивающих условия для установления личности правонарушителя, составления протокола об административном правонарушении и т.д. ${ }^{18}$. К их числу относятся, например, такие меры как доставление, изъятие вещей и документов, привод, арест товаров, транспортных средств и иных вещей и т.д. ${ }^{19}$.

Однако, несмотря на расхождения авторов в предложенных классификациях видов административного принуждения, указанные меры имеют общий ключевой признак, сущность которого заключается в том, что они несут в себе негативные последствия для правонарушителя, в отношении которого они применяются, и последний, в свою очередь, претерпевает лишения личного, имущественного и организационного характера. В связи с изложенным, нельзя не отметить попытку ряда публикаций осуществить подмену юридических понятий. Так, в отчёте о научно-исследовательской работе по теме: «Актуальные вопросы совершенствования правового регулирования в области бюджетных отношений», выполненного в 2013 году в Финансовом университете при Правительстве Российской Федерации авторский коллектив предлагает отказаться от категории «меры принуждения», «заменив её более нейтральной, такой, например, как «меры юридического воздействия»» ${ }^{20}$. Указанный вывод нельзя признать обоснованным с доктринальной точки зрения. Термин «юридическое воздействие», по мнению авторов настоящей статьи, более приемлем для понятия «бюджетное

\footnotetext{
15 См.: там же.

16 См.: там же.

17 См. там же. С. 205.

18 См.: там же.

19 См.: там же. С. 205 - 206.

20 Отчёт по НИР «Актуальные вопросы совершенствования правового регулирования в области бюджетных
} 
правоотношение», так как воздействие в отличие от принуждения предполагает не только негативные, но и позитивные воздействия для участников правоотношений в виде предоставления определённых льгот и преференций.

\section{Правонарушения в бюджетной сфере в КоАП РФ и БК РФ: сравнительный анализ норм}

Анализ составов административных правонарушений в области бюджетных отношений, изложенных в главе 15 КоАП РФ «Административные правонарушения в области финансов, налогов и сборов, страхования и рынка ценных бумаг», позволяет предложить несколько условных классификаций противоправных деяний в зависимости от конкретного сегмента административного управленческого правоотношения, составляющего порядок осуществления взаимодействия с финансовым органом.

Первый сегмент. Порядок пользования бюджетными средствами.

Таблица 1.

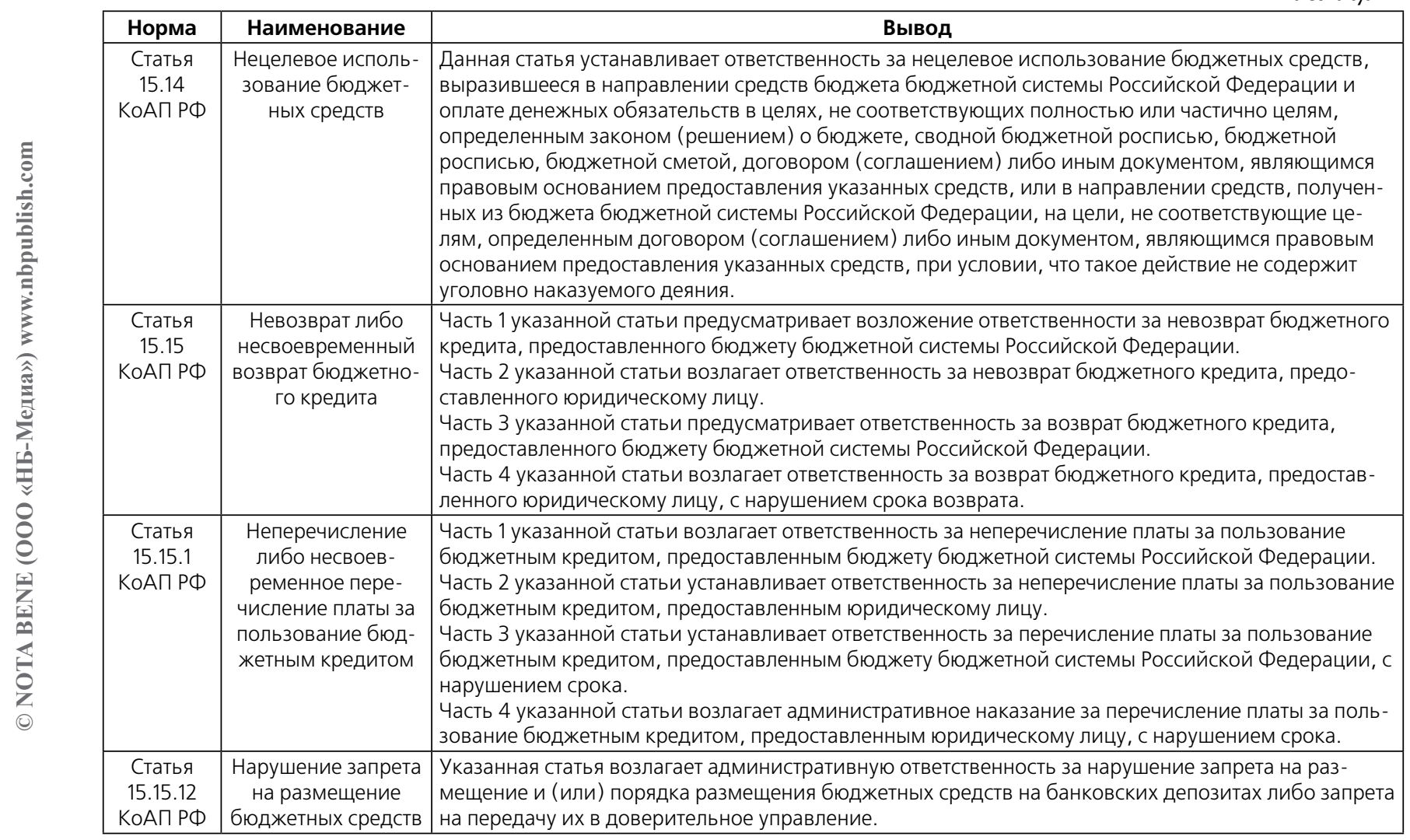

Второй сегмент. Порядок предоставления межбюджетных трансфертов, бюджетных кредитов, инвестиций и субсидий.

Третий сегмент. Порядок предоставления бюджетной и платёжной документации и представлений органа Федерального казначейства.

отношений» (научный руководитель, д.ю.н., профессор А.А. Фатьянов). М., Финуниверситет, 2013. С. 14. // Текст отчёта размещён на информационно-образовательном портале Финуниверситета. 


\section{Административное и муниципальное право и институты гражданского общества}

Таблица 2.

\begin{tabular}{|c|c|c|}
\hline Норма & Наименование & Вывод \\
\hline $\begin{array}{c}\text { Статья } \\
15.15 .2 \\
\text { КоАП РФ }\end{array}$ & $\begin{array}{c}\text { Нарушение условий } \\
\text { предоставления бюджетного } \\
\text { кредита }\end{array}$ & $\begin{array}{l}\text { Часть } 1 \text { указанной статьи налагает санкции за нарушение условий предоставления бюд- } \\
\text { жетного кредита, за исключением случаев, предусмотренных статьёй } 15.14 \text { КоАП РФ. } \\
\text { Часть } 2 \text { указанной статьи налагает санкции за нарушение заемщиком условий предостав- } \\
\text { ления бюджетного кредита, предоставленного бюджету бюджетной системы Российской } \\
\text { Федерации, за исключением случаев, предусмотренных статьей } 15.14 \text { КоАП РФ. Часть } \\
3 \text { указанной статьи возлагает ответственность за нарушение заемщиком условий предо- } \\
\text { ставления бюджетного кредита, предоставленного юридическому лицу, за исключением } \\
\text { случаев, предусмотренных статьей } 15.14 \text { КоАП РФ. }\end{array}$ \\
\hline $\begin{array}{c}\text { Статья } \\
15.15 .3 \\
\text { КоАП РФ }\end{array}$ & $\begin{array}{c}\text { Нарушение условий предо- } \\
\text { ставления межбюджетных } \\
\text { трансфертов }\end{array}$ & $\begin{array}{l}\text { Статья возлагает административную ответственность за нарушение главным распоря- } \\
\text { дителем бюджетных средств, предоставляющим межбюджетные трансферты, и (или) } \\
\text { финансовым органом, главным распорядителем (распорядителем), получателем средств } \\
\text { бюджета, которому предоставлены межбюджетные трансферты, условий их предоставле- } \\
\text { ния, за исключением случаев, предусмотренных статьей } 15.14 \text { КоАП РФ. } \\
\end{array}$ \\
\hline $\begin{array}{c}\text { Статья } \\
15.15 .4 \\
\text { КоАП РФ }\end{array}$ & $\begin{array}{c}\text { Нарушение условий } \\
\text { предоставления бюджетных } \\
\text { инвестиций }\end{array}$ & $\begin{array}{l}\text { Указанная статья состоит из двух частей. } \\
\text { Часть } 1 \text { указанной статьи возлагает ответственность за нарушение главным распорядите- } \\
\text { лем бюджетных средств, предоставляющим бюджетные инвестиции, условий их предо- } \\
\text { ставления, за исключением случаев, предусмотренных статьей } 15.14 \text { КоАП РФ. } \\
\text { Часть } 2 \text { указанной статьи устанавливает административные санкции за нарушение юриди- } \\
\text { ческим лицом, которому предоставлены бюджетные инвесиции, условий их предостав- } \\
\text { ления, за исключением случаев, предусмотренных статьей } 15.14 \text { КоАП РФ. }\end{array}$ \\
\hline $\begin{array}{c}\text { Статья } \\
15.15 .5 \\
\text { КоАП РФ }\end{array}$ & $\begin{array}{l}\text { Нарушение условий предо- } \\
\text { ставление субсидий }\end{array}$ & $\begin{array}{l}\text { Данная статья состоит из двух частей. Часть } 1 \text { указанной статьи возлагает ответственность } \\
\text { за нарушение главным распорядителем бюджетных средств, предоставляющим субсидии } \\
\text { юридическим лицам, индивидуальным предпринимателям, физическим лицам, условий } \\
\text { их предоставления, за исключением случаев, предусмотренных статьей } 15.14 \text { КоАП РФ. } \\
\text { Часть } 2 \text { указанной статьи налагает административную санкцию за нарушение юридиче- } \\
\text { ским лицом, индивидуальным предпринимателем, физическим лицом, являющимися } \\
\text { получателями субсидий, условий их предоставления, за исключением случаев, предусмо- } \\
\text { тренных статьей 15.14КоАП РФ. }\end{array}$ \\
\hline $\begin{array}{c}\text { Статья } \\
15.15 .8 \\
\text { КоАП РФ. }\end{array}$ & $\begin{array}{c}\text { Нарушение запрета на } \\
\text { предоставление бюджетных } \\
\text { кредитов и (или) субсидий }\end{array}$ & $\begin{array}{l}\text { Данная статья возлагает ответственность за нарушение запрета на предоставление казен- } \\
\text { ному учреждению бюджетных кредитов и (или) субсидий. }\end{array}$ \\
\hline
\end{tabular}

таблица 3.

\begin{tabular}{|c|c|c|}
\hline Норма & Наименование & Вывод \\
\hline $\begin{array}{c}\text { Статья } \\
15.15 .6 \\
\text { КоАП РФ }\end{array}$ & $\begin{array}{c}\text { Нарушение порядка } \\
\text { представления бюд- } \\
\text { жетной отчетности }\end{array}$ & $\begin{array}{l}\text { Указанная статья возлагает административную ответственность за непредставление или пред- } \\
\text { ставление с нарушением сроков, установленных бюджетным законодательством и иными } \\
\text { нормативными правовыми актами, регулирующими бюджетные правоотношения, бюджетной } \\
\text { отчетности или иных сведений, необходимых для составления и рассмотрения проектов бюджетов } \\
\text { бюджетной системы Российской Федерации, исполнения бюджетов бюджетной системы Россий- } \\
\text { ской Федерации, либо представление заведомо недостоверной бюджетной отчетности или иных } \\
\text { сведений, необходимых для составления и рассмотрения проектов бюджетов бюджетной системы } \\
\text { Российской Федерации, исполнения бюджетов бюджетной системы Российской Федерации. }\end{array}$ \\
\hline $\begin{array}{c}\text { Статья } \\
15.15 .7 \\
\text { КоАП РФ }\end{array}$ & $\begin{array}{c}\text { Нарушение порядка } \\
\text { составления, утверж- } \\
\text { дения и ведения бюд- } \\
\text { жетных смет } \\
\end{array}$ & $\begin{array}{l}\text { Данная статья возлагает ответственность за нарушение казенным учреждением порядка состав- } \\
\text { ления, утверждения и ведения бюджетных смет или порядка учета бюджетных обязательств. }\end{array}$ \\
\hline $\begin{array}{c}\text { Статья } \\
15.15 .9 \\
\text { КоАП РФ }\end{array}$ & $\begin{array}{l}\text { Несоответствие } \\
\text { бюджетной росписи } \\
\text { сводной бюджетной } \\
\quad \text { росписи }\end{array}$ & $\begin{array}{l}\text { Указанная статья устанавливает административную ответственность за несоответствие бюджет- } \\
\text { ной росписи сводной бюджетной росписи, за исключением случаев, когда такое несоответствие } \\
\text { допускается Бюджетным кодексом Российской Федерации, за исключением случаев, предусмо- } \\
\text { тренных статьей } 15.14 \text { КоАП РФ. }\end{array}$ \\
\hline $\begin{array}{c}\text { Статья } \\
15.15 .16 \\
\text { КоАП РФ }\end{array}$ & $\begin{array}{c}\text { Нарушение испол- } \\
\text { нения платежных } \\
\text { документов и пред- } \\
\text { ставления органа } \\
\text { Федерального казна- } \\
\text { чейства }\end{array}$ & $\begin{array}{l}\text { Часть } 1 \text { указанной статьи устанавливает административную ответственность за неисполнение или } \\
\text { несвоевременное исполнение банком или иной кредитной организацией платежных документов } \\
\text { на перечисление средств, подлежащих зачислению на счета бюджетов бюджетной системы Рос- } \\
\text { сийской Федерации (за исключением доходов, контроль за исчислением, полнотой и своевремен- } \\
\text { ностью уплаты (перечисления) которых в бюджеты осуществляют налоговые органы, таможенные } \\
\text { органы, органы управления государственными внебюджетными фондами и судебные приставы), } \\
\text { либо на перечисление средств бюджетов бюджетной системы Российской Федерации. } \\
\text { Часть } 2 \text { указанной статьи устанавливает административную санкцию за неисполнение банком или } \\
\text { иной кредитной организацией представления органа Федерального казначейства о приостановле- } \\
\text { нии операций по счетам, открытым казенным и бюджетным учреждениям в нарушение бюджетно- } \\
\text { го законодательства Российской Федерации и иных нормативных правовых актов, регулирующих } \\
\text { бюджетные правоотношения, либо по счетам в валюте Российской Федерации по учету средств } \\
\text { бюджетов субъектов Российской Федерации (муниципальных образований), открытым финансо- } \\
\text { вым органам субъектов Российской Федерации (муниципальных образований). }\end{array}$ \\
\hline
\end{tabular}


Административное и муниципальное право 1 (85) • 2015

Четвёртый сегмент. Порядок принятия бюджетных обязательств.

Таблица 4.

\begin{tabular}{|c|c|c|}
\hline Норма & Наименование & Вывод \\
\hline $\begin{array}{l}\text { Статья } \\
15.15 .10 \\
\text { КоАП РФ }\end{array}$ & $\begin{array}{c}\text { Нарушение порядка принятия } \\
\text { бюджетных обязательств }\end{array}$ & $\begin{array}{l}\text { устанавливает административную ответственность за принятие бюджетных обяза- } \\
\text { тельств в размерах, превышающих утвержденные бюджетные ассигнования и (или) } \\
\text { лимиты бюджетных обязательств, за исключением случаев, предусмотренных бюджет- } \\
\text { ным законодательством Российской Федерации и иными нормативными правовыми } \\
\text { актами, регулирующими бюджетные правоотношения. }\end{array}$ \\
\hline $\begin{array}{c}\text { Статья } \\
15.15 .11 \\
\text { КоАП РФ }\end{array}$ & $\begin{array}{l}\text { Нарушение сроков доведения } \\
\text { бюджетных ассигнований и } \\
\text { (или) лимитов бюджетных } \\
\text { обязательств }\end{array}$ & $\begin{array}{l}\text { Указанная статья устанавливает административную ответственность за несвоевремен- } \\
\text { ное доведение до распорядителей или получателей бюджетных средств бюджетных } \\
\text { ассигнований и (или) лимитов бюджетных обязательств. }\end{array}$ \\
\hline
\end{tabular}

Пятый сегмент. Порядок обслуживания государственного долга.

Таблица 5.

\begin{tabular}{|c|c|l|}
\hline Норма & Наименование & Вывод \\
\hline Статья & Нарушение сроков обслуживания и & Данная статья устанавливает ответственность за нарушение сроков обслужи- \\
15.15 .13 & погашения государственного (муници- & вания и погашения государственного (муниципального) долга. \\
КоАП РФ & пального) долга. & \\
\hline
\end{tabular}

Шестой сегмент. Порядок направления информации о рассмотрении дела в суде.

таблица 6.

\begin{tabular}{|c|c|c|}
\hline Норма & Наименование & Вывод \\
\hline $\begin{array}{c}15.15 .14 \\
\text { КоАП РФ }\end{array}$ & $\begin{array}{l}\text { Нарушение срока направле- } \\
\text { ния информации о результа- } \\
\text { тах рассмотрения дела в суде }\end{array}$ & $\begin{array}{l}\text { Данная статья устанавливает административную ответственность за несоблюдение глав- } \\
\text { ным распорядителем бюджетных средств, представлявшим в суде интересы Российской } \\
\text { Федерации, субъекта Российской Федерации или муниципального образования, срока } \\
\text { направления в соответствующий финансовый орган информации о результатах рассмо- } \\
\text { трения дела, о наличии оснований и результатах обжалования судебного акта. }\end{array}$ \\
\hline
\end{tabular}

Седьмой сегмент. Порядок формирования государственного задания.

таблица 7.

\begin{tabular}{|c|c|c|}
\hline Норма & Наименование & \multicolumn{1}{c|}{ Вывод } \\
\hline 15.15 .15 & $\begin{array}{c}\text { Нарушение порядка форми- } \\
\text { Кован РФ } \\
\text { (муния государственного } \\
\text { (мунцпального) задания }\end{array}$ & $\begin{array}{l}\text { Данна статья устанавливает административную ответственность за нарушение порядка } \\
\text { ципального) задания, за исключением случаев, предусмотренных статьей 15.14 КоАП РФ. }\end{array}$ \\
\hline
\end{tabular}

Глава 30 Бюджетного кодекса РФ содержит 5 (пять) статей (ст.ст. 306.4 - 306. 8 БК РФ), в которых формулируются 6 (шесть) составов бюджетных правонарушений и перечень бюджетных мер, применяемых за их совершение. Как и в случае с анализом КоАП РФ, целесообразно предложить несколько условных классификаций противоправных деяний в зависимости от конкретного сегмента административного управленческого правоотношения, составляющего порядок осуществления взаимодействия с финансовым органом.

Первый сегмент. Порядок пользования бюджетными средствами.

Таблица 8.

\begin{tabular}{|c|c|l|}
\hline Норма & Наименование & \multicolumn{1}{c|}{ Вывод } \\
\hline Статья & Нецелевое ис- & Часть 1 указанной статьи формулирует понятие нецелевого использования бюджетных средств, под \\
306.4 & пользование & которым признаётся направление средств бюджета бюджетной системы Российской Федерации и \\
БК РФ & бюджетных & оплата денежных обязательств в целях, соответствующих полностью и частично целям, определённым \\
& средств & законом (решением) о бюджете, сводной бюджетной росписью, бюджетной сметой, договором (со- \\
& & глашением) либо иным документом, являющимся основанием предоставления указанных средств. \\
\hline
\end{tabular}


Продолжение таблицы

\begin{tabular}{|c|c|c|}
\hline Норма & Наименование & Вывод \\
\hline & & $\begin{array}{l}\text { Часть } 2 \text { указанной статьи устанавливает меру бюджетного принуждения за нецелевое использование } \\
\text { бюджетных средств, совершенное главным распорядителем бюджетных средств, распорядителем } \\
\text { бюджетных средств, получателем бюджетных средств, в виде передачи уполномоченному по со- } \\
\text { ответствующему бюджету части полномочий главного распорядителя, распорядителя и получателя } \\
\text { бюджетных средств. } \\
\text { Часть } 3 \text { указанной статьи содержит две меры бюджетного принуждения: во-первых, бесспорное } \\
\text { взыскание суммы средств, полученных из другого бюджета бюджетной системы Российской Феде- } \\
\text { рации; во-вторых, плата за пользование ими либо приостановление (сокращение) предоставления } \\
\text { межбюджетных трансфертов (за исключением субвенций). Обе санкции налагаются за нецелевое } \\
\text { использование бюджетных средств, выразившееся в нецелевом использовании финансовыми орга- } \\
\text { нами (главными распорядителями (распорядителями) и получателями средств бюджета, которому } \\
\text { предоставлены межбюджетные трансферты) межбюджетных субсидий, субвенций и иных межбюд- } \\
\text { жетных трансфертов, имеющих целевое назначение, а также кредитов бюджетам бюджетной системы } \\
\text { Российской Федерации. }\end{array}$ \\
\hline $\begin{array}{c}\text { Статья } \\
306.7 \\
\text { БК РФ }\end{array}$ & $\begin{array}{c}\text { Наруше- } \\
\text { ние условий } \\
\text { предоставления } \\
\text { бюджетного } \\
\text { кредита }\end{array}$ & $\begin{array}{l}\text { Данная статья устанавливает ответственность за нарушение финансовым органом условий предо- } \\
\text { ставления бюджетного кредита, предоставленного одному бюджету бюджетной системы Российской } \\
\text { Федерации из другого бюджета бюджетной системы Российской Федерации, если это действие не } \\
\text { связано с нецелевым использованием бюджетных средств. }\end{array}$ \\
\hline
\end{tabular}

Второй сегмент. Порядок предоставления меж-

бюджетных трансфертов, бюджетных кредитов.

Таблица 9.

\begin{tabular}{|c|c|c|}
\hline Норма & Наименование & Вывод \\
\hline $\begin{array}{l}\text { Статья } \\
306.5 \\
\text { БКРФ }\end{array}$ & $\begin{array}{c}\text { Невозврат либо несвоевре- } \\
\text { менный возврат бюджетного } \\
\text { кредита }\end{array}$ & $\begin{array}{l}\text { Данная статья предусматривает бесспорное взыскание суммы непогашенного остатка } \\
\text { бюджетного кредита и пеней за несвоевременный возврат бюджетного кредита в раз- } \\
\text { мере одной трёхстой действующей ставки рефинансирования Центрального банка } \\
\text { Российской Федерации за каждый день просрочки и (или) приостановление предостав- } \\
\text { ления межбюджетных трансфертов (за исключением субвенций) бюджету, которому } \\
\text { предоставлен бюджетный кредит, на сумму непогашенного остатка бюджетного кредита. }\end{array}$ \\
\hline $\begin{array}{l}\text { Статья } \\
306.6 \\
\text { БКРФ }\end{array}$ & $\begin{array}{c}\text { Неперечисление либо не- } \\
\text { своевременное перечисление } \\
\text { платы за пользование бюд- } \\
\text { жетным кредитом }\end{array}$ & $\begin{array}{l}\text { Данная статья предусматривает наложение санкции в виде бесспорного взыскания сум- } \\
\text { мы платы за пользование бюджетным кредитом и пеней за ее несвоевременное пере- } \\
\text { числение в размере одной трехсотой действующей ставки рефинансирования Централь- } \\
\text { ного банка Российской Федерации за каждый день просрочки и (или) приостановление } \\
\text { предоставления межбюджетных трансфертов (за исключением субвенций) бюджету, } \\
\text { которому предоставлен бюджетный кредит, на сумму непогашенного остатка платы за } \\
\text { пользование бюджетным кредитом. }\end{array}$ \\
\hline $\begin{array}{l}\text { Статья } \\
306.8 \\
\text { БК РФ }\end{array}$ & $\begin{array}{c}\text { Нарушение условий предо- } \\
\text { ставления межбюджетных } \\
\text { трансфертов }\end{array}$ & $\begin{array}{l}\text { Указанная статья устанавливает ответственность за нарушение финансовым органом } \\
\text { (главным распорядителем (распорядителем) и получателем средств бюджета, которому } \\
\text { предоставлены межбюджетные трансферты) условий предоставления межбюджетных } \\
\text { трансфертов, если это действие не связано с нецелевым использованием бюджетных } \\
\text { средств. } \\
\text { В указанном случае возможно наложение санкция в виде бесспорного взыскания суммы } \\
\text { межбюджетного трансферта и (или) приостановление (сокращение) предоставления } \\
\text { межбюджетных трансфертов (за исключением субвенций). }\end{array}$ \\
\hline
\end{tabular}

Таким образом, объектами правонарушений, содержащихся в главе в главе 30 Бюджетного кодекса РФ, выступают два сегмента правоотношений, составляющих порядок осуществления взаимодействий с финансовыми органами.

Сравнительный анализ норм КоАП РФ и БК РФ позволяет констатировать определённый дисбаланс, сложившийся между КоАП РФ и БК РФ в количестве норм, налагающих юридическую ответственность за бюджетные правонарушения. Наибольшее количество составов право- нарушений, совершаемых в бюджетной сфере, сформулировано в КоАП РФ. Если в КоАП РФ выделено 7 (семь) сегментов правоотношений, составляющих объекты составов административных правонарушений в бюджетной сфере, то в БК РФ выделено 2 (два) сегмента правоотношений, составляющих объекты составов бюджетных правонарушений.

Для удобства сопоставления объектов составов бюджетных правонарушений приведём следующую таблицу. 
Таблица 10.

\begin{tabular}{|c|c|}
\hline \multicolumn{2}{|c|}{ СРАВНИТЕЛЬНАЯ ТАБЛИЦА ОБЪЕКТОВ БЮДЖЕТНЫХ ПРАВОНАРУШЕНИЙ КОАП РФ И НК РФ } \\
\hline КОДЕКС ОБ АДМИНИСТРАТИВНЫХ ПРАВОНАРУШЕНИЯХ РФ & БЮДЖЕТНЫЙ КОДЕКС РФ \\
\hline $\begin{array}{c}\text { Первый сегмент. Порядок пользования бюджетными средствами } \\
(15.4 .-15.15 .1,15.15 .12 \text { КоАП РФ). }\end{array}$ & $\begin{array}{c}\text { Первый сегмент. Порядок пользования бюджетными сред- } \\
\text { ствами (ст.306.4, 306.7 БК РФ). }\end{array}$ \\
\hline $\begin{array}{c}\text { Второй сегмент. Порядок предоставления межбюджетных транс- } \\
\text { фертов, бюджетных кредитов, инвестиций и субсидий (15.15.2 - } \\
\text { 15.15.5, 15.15.8 КоАП РФ). }\end{array}$ & $\begin{array}{c}\text { Второй сегмент. Порядок предоставления межбюджетных } \\
\text { трансфертов, бюджетных кредитов, инвестиций и кредитов. } \\
\text { (ст.ст. 306.5, 306.6, 306.8 БК РФ). }\end{array}$ \\
\hline $\begin{array}{c}\text { Третий сегмент. Порядок предоставления бюджетной и платёжной } \\
\text { документации и представлений органа Федерального казначей- } \\
\text { ства }(15.15 .6,15.15 .7,15.15 .9 \text { КоАП РФ) }\end{array}$ & \\
\hline $\begin{array}{l}\text { Четвёртый сегмент. Порядок принятия бюджетных обязательств } \\
(15.15 .10-15.15 .12 \text { КоАП РФ). }\end{array}$ & \\
\hline $\begin{array}{l}\text { Пятый сегмент. Порядок обслуживания государственного долга } \\
(15.15 .13 \text { КоАП РФ). }\end{array}$ & \\
\hline $\begin{array}{c}\text { Шестой сегмент. Порядок направления информации о рассмотре- } \\
\text { нии дела в суде (15.15.14 КоАП РФ). }\end{array}$ & \\
\hline $\begin{array}{c}\text { Седьмой сегмент. Порядок формирования государственного за- } \\
\text { дания (15.15.15 КоАП РФ) }\end{array}$ & \\
\hline
\end{tabular}

Сравнительный анализ позволяет выявить типологические сходства между объектами правонарушений в бюджетной сфере, содержащимися в КоАП РФ и БК РФ. В основе указанного сходства лежит тождественность объектов правонарушений, формально-юридически, зафиксированных в кодифицированных актах.

К таковым следует отнести:

По первому сегменту рассматриваемых бюджетных правоотношений (порядок пользования бюджетными средствами): статья 15.14 КоАП РФ (нецелевое использование бюджетных средств) и статья 306.4 БК РФ (нецелевое использование бюджетных средств); статья 15.15 (невозврат либо несвоевременный возврат бюджетного кредита) и статья 306.5 БК РФ (невозврат либо несвоевременный возврат бюджетного кредита); статья 15.15.1 КоАП РФ (неперечисление либо несвоевременное перечисление платы за пользование бюджетным кредитом) и статья 306.6 БК РФ (неперечисление либо несвоевременное перечисление платы за пользование бюджетным кредитом);

По второму сегменту рассматриваемых правоотношений (порядок предоставления межбюджетных трансфертов, бюджетных кредитов, инвестиций и субсидий): статья 15.15.2 КоАП РФ (нарушение условий предоставления бюджетного кредита) и статья 306.7 БК РФ (нарушение условий предоставления бюджетного кредита); статья 15.15 КоАП РФ (невозврат либо несвоевременный возврат бюджетного кредита) и статья 306.5 БК РФ (невозврат либо несвоевременный возврат бюджетного кредита); статья 15.15.3 КоАП РФ (нарушение условий предоставления межбюджетных трансфертов) и статья 306.8 БК РФ (нарушение условий предоставления межбюджетных трансфертов).

Однако, несмотря на однородность объектов составов правонарушений, зафиксированных в соответствующих статьях КоАП РФ и БК РФ, данные составы формально-юридически закреплены в различных кодифицированных актах. Причинами данного разграничения являются: во-первых, субъектный состав участников бюджетных правоотношений и потенциальных правонарушителей бюджетного законодательства, зафиксированный в БК РФ и КоАП РФ; во-вторых, специальные принудительные меры для правонарушителей, прописанные в БК РФ.

Так, статья 15.14 КоАП РФ (нецелевое использование бюджетных средств) предусматривает в виде санкций наложение административного штрафа на должностных лиц в размере от двадцати тысяч до пятидесяти тысяч рублей или дисквалификацию на срок от одного года до трех лет; на юридических лиц - от 5 до 25 процентов суммы средств, полученных из бюджета бюджетной системы Российской Федерации, использованных не по целевому назначению;

Часть 2 статья 306.4 БК РФ (нецелевое использование бюджетных средств) устанавливает, что субъектами ответственности по данному составу правонарушения выступают финансовые органы в лице главного распорядителя бюджетных средств, распорядителя бюджетных средств и получатель бюджетных средств, и влечёт за собой наложение санкций в виде передачи уполномоченному по соответствующему бюджету части полномочий главного распорядителя, распорядителя и получателя бюджетных средств. 
Часть 3 указанной статьи устанавливает, что субъектами правонарушения могут выступать финансовые органы (главные распорядители (распорядители) и получатели средств бюджета, которым предоставлены межбюджетные трансферты), для которых устанавливаются санкции в виде бесспорного взыскания суммы средств, полученных из другого бюджета бюджетной системы Российской Федерации, и платы за пользование ими либо приостановление (сокращение) предоставления межбюджетных трансфертов (за исключением субвенций).

Статья 15.15 КоАП РФ (невозврат либо несвоевременный возврат бюджетного кредита) в качестве субъектов данного правонарушения устанавливает должностных лиц, на которых налагается штраф в размере от двадцати тысяч до пятидесяти тысяч рублей (ч.ч. 1-2) от десяти тысяч до тридцати тысяч рублей (ч.ч. 3-4); юридических лиц, на которых налагается административный штраф от 5 до 25 процентов суммы бюджетного кредита, не перечисленной в установленный срок на счета бюджетов бюджетной системы Российской Федерации (часть 2).

Статья 306.5 БК РФ (невозврат либо несвоевременный возврат бюджетного кредита), устанавливает, что субъектами данного правонарушения выступают финансовые органы, на которых налагаются санкции в виде бесспорного взыскания суммы непогашенного остатка бюджетного кредита и пеней за его несвоевременный возврат в размере одной трехсотой действующей ставки рефинансирования Центрального банка Российской Федерации за каждый день просрочки и (или) приостановление предоставления межбюджетных трансфертов (за исключением субвенций) бюджету, которому предоставлен бюджетный кредит, на сумму непогашенного остатка бюджетного кредита.

Статья 15.15.1 КоАП РФ (невозврат либо несвоевременный возврат бюджетного кредита) предусматривает в виде санкций наложение административного штрафа на должностных лиц в размере от двадцати тысяч до пятидесяти тысяч рублей (часть 1); наложение административного штрафа на должностных лиц в размере от двадцати тысяч до пятидесяти тысяч рублей; на юридических лиц - от 5 до 25 процентов суммы бюджетного кредита, не перечисленной в установленный срок на счета бюджетов бюджетной системы Российской Федерации (часть 2); наложение административного штрафа на должностных лиц в размере от десяти тысяч до тридцати тысяч рублей (часть 3); наложение адми- нистративного штрафа на должностных лиц в размере от десяти тысяч до тридцати тысяч рублей; на юридических лиц - от 2 до 12 процентов суммы бюджетного кредита, не перечисленной в установленный срок на счета бюджетов бюджетной системы Российской Федерации (часть 4).

Статья 306.6 БК РФ (неперечисление либо несвоевременное перечисление платы за пользование бюджетным кредитом) устанавливает, что субъектом данного состава правонарушения выступает финансовый орган и налагает на последний санкцию в виде бесспорного взыскания суммы платы за пользование бюджетным кредитом и пеней за ее несвоевременное перечисление в размере одной трехсотой действующей ставки рефинансирования Центрального банка Российской Федерации за каждый день просрочки и (или) приостановление предоставления межбюджетных трансфертов (за исключением субвенций) бюджету, которому предоставлен бюджетный кредит, на сумму непогашенного остатка платы за пользование бюджетным кредитом.

Статья 15.15.2 КоАП РФ (нарушение условий предоставления бюджетного кредита) предусматривает в виде административных санкций наложение административного штрафа на должностных лиц в размере от десяти тысяч до тридцати тысяч рублей или дисквалификацию на срок от одного года до двух лет (часть 1); наложение административного штрафа на должностных лиц в размере от десяти тысяч до тридцати тысяч рублей или дисквалификацию на срок от одного года до двух лет (часть 2); наложение административного штрафа на должностных лиц в размере от десяти тысяч до тридцати тысяч рублей; на юридических лиц - от 2 до 12 процентов суммы полученного бюджетного кредита (часть 3 ).

Статья 306.7 БК РФ (нарушение условий предоставления бюджетного кредита) устанавливает, что субъектом данного правонарушения выступает финансовый орган, на который за содеянное налагаются санкции в виде бесспорного взыскания суммы бюджетного кредита и (или) платы за пользование им и (или) приостановление предоставления межбюджетных трансфертов (за исключением субвенций).

Статья 15.15.3 КоАП РФ (нарушение условий предоставления межбюджетных трансфертов) устанавливает санкции в виде административного штрафа на должностных лиц в размере от десяти тысяч до тридцати тысяч рублей или дисквалификацию на срок от одного года до двух лет. 
Статья 306.8 БК РФ (нарушение условий предоставления межбюджетных трансфертов) устанавливает, что субъектом данного правонарушения выступает финансовый орган (главный распорядитель и получатель средств бюджета, которому предоставлены межбюджетные трансферты) и устанавливает санкции в виде бесспорного взыскания суммы межбюджетного трансферта и (или) приостановление (сокращение) предоставления межбюджетных трансфертов (за исключением субвенций).

Субъектами административных правонарушений, предусмотренных ст.ст. 15.14. - 15.15.3 КоАП РФ выступают должностные лица, под которыми в соответствии со ст. 2.4 КоАП РФ понимается лицо, постоянно, временно или в соответствии со специальными полномочиями осуществляющее функции представителя власти, то есть наделенное в установленном законом порядке распорядительными полномочиями в отношении лиц, не находящихся в служебной зависимости от него, а равно лицо, выполняющее организационно-распорядительные или административно-хозяйственные функции в государственных органах, органах местного самоуправления, государственных и муниципальных организациях, а также в Вооруженных Силах Российской Федерации, других войсках и воинских формированиях Российской Федерации.

Субъектами правонарушений в бюджетной сфере в соответствии с нормами, предусмотренными в статьях 306.4 - 306.8 БК РФ являются финансовые органы, под которыми статья 6 БК РФ понимает Министерство финансов Российской Федерации, органы исполнительной власти субъектов Российской Федерации, осуществляющие составление и организацию исполнения бюджетов субъектов Российской Федерации (финансовые органы субъектов Российской Федерации), органы (должностные лица) местных администраций муниципальных образований, осуществляющие составление и организацию исполнения местных бюджетов (финансовые органы муниципальных образований).

Правовая специфика данного понятия заключается в том, что оно носит синкретический характер, так как включает как органы исполнительной власти, обладающих статусом юридических лиц, так и собственно должностных лиц, подпадающих под признаки, предусмотренных ст. 2.4 КоАП РФ.

Должностные лица и юридические лица являются субъектами административных правонарушений, следовательно, составы правонарушений, предусмотренные статьями 306.4 - 306.8 БК РФ, по сути, дублируют составы правонарушений, из- ложенные в статьях 15.14. - 15.15.3 КоАП РФ, но при этом содержат специфические бюджетные меры принуждения, которых нет в перечне административных наказаний, предусмотренных КоАП РФ. Данное обстоятельство вызвано стремлением законодателя повысить уровень мер государственного принуждения и юридической ответственности финансовых органов за выполнение возложенных на них полномочий.

\section{Меры государственного принуждения в административном и бюджетном законодательстве: сравнительный анализ норм}

Для удобства сопоставления санкций за правонарушения в бюджетной сфере, содержащихся в КоАП РФ и БК РФ, приведём следующую таблицу.

Таблица 11.

\begin{tabular}{|c|c|}
\hline $\begin{array}{l}\text { Меры админи- } \\
\text { стративных } \\
\text { наказаний } \\
\text { Кодекс Российской } \\
\text { Федерации об ад- } \\
\text { министративных } \\
\text { правонарушениях }\end{array}$ & $\begin{array}{c}\text { Особые бюджетные меры } \\
\text { государственного принуждения } \\
\text { Бюджетный кодекс } \\
\text { Российской Федерации } \\
\text { (часть } 2 \text { ст. 306.2 БК РФ) }\end{array}$ \\
\hline $\begin{array}{c}\text { Административный } \\
\text { штраф }\end{array}$ & $\begin{array}{l}\text { Передача уполномоченному по соответ- } \\
\text { ствующему бюджету части полномочий } \\
\text { главного распорядителя, распорядителя } \\
\text { и получателя бюджетных средств }\end{array}$ \\
\hline \multirow[t]{4}{*}{ Дисквалифкация } & $\begin{array}{l}\text { Бесспорное взыскание суммы средств, } \\
\text { полученных из другого бюджета бюд- } \\
\text { жетной системы Российской Федера- } \\
\text { ции, и платы за пользование ими }\end{array}$ \\
\hline & $\begin{array}{l}\text { Приостановление (сокращение) предо- } \\
\text { ставления межбюджетных трансфертов } \\
\text { (за исключением субвенций) }\end{array}$ \\
\hline & $\begin{array}{l}\text { Бесспорное взыскание суммы платы за } \\
\text { пользование бюджетным кредитом и } \\
\text { пеней за ее несвоевременное пере- } \\
\text { числение в размере одной трехсотой } \\
\text { действующей ставки рефинансирования } \\
\text { Центрального банка Российской Феде- } \\
\text { рации за каждый день просрочки }\end{array}$ \\
\hline & $\begin{array}{l}\text { Бесспорное взыскание суммы бюджет- } \\
\text { ного кредита и (или) платы за пользо- } \\
\text { вание им }\end{array}$ \\
\hline
\end{tabular}

Авторы настоящей статьи считают, что к бюджетным мерам принуждения, перечень которых содержится в части 2 статьи 306.2 БК РФ, может быть применена классификация мер административного принуждения, предложенная Л.Л. Поповым. Кроме того, применительно к бюджетным мерам принуждения, по нашему мнению, обоснованной является позиция Д.Н. Бахраха о наличии восстановительных мер. 
Обратимся к содержанию указанных мер на предмет их соотнесения с классификацией видов мер административного принуждения, предложенных учёными-административистами:

1. Бесспорное взыскание суммы средств, предоставленных из одного бюджета бюджетной системы Российской Федерации другому бюджету бюджетной системы Российской Федерации. Данная мера носит восстановительный характер, так как призвана компенсировать незаконно полученные бюджетные средства из одного бюджета другому бюджету;

2. Бесспорное взыскание суммы платы за пользование средствами, предоставленными из одного бюджета бюджетной системы Российской Федерации другому бюджету бюджетной системы Российской Федерации. Указанная мера также носит восстановительный характер, так как призвана компенсировать расходы за пользование бюджетными средствами, предоставленными из одного бюджета другому бюджету;

3. Бесспорное взыскание пеней за несвоевременный возврат средств бюджета. Указанная мера, по сути, представляет собой самостоятельную меру ответственности или наказания за совершённое правонарушение;

4. Приостановление (сокращение) предоставления межбюджетных трансфертов (за исключением субвенций). Данная мера носит пресекательный характер, так как направлена на принудительное прекращение противоправных действий нарушителя в момент совершения противоправных действий;

5. Передача уполномоченному по соответствующему бюджету части полномочий главного распорядителя, распорядителя и получателя бюджетных средств. Данная мера, по мнению авторов, носит пресекательный характер, так как направлена на принудительное прекращение противоправных действий нарушителя в момент совершения противоправных действий, и в то же время, может рассматриваться как мера процессуального характера, поскольку направлена на передачу части процессуальных полномочий от одного субъекта другому, что в конечном итоге призвано обеспечить пресечение правонарушение и привлечение лица к ответственности.

Указанные в части 2 статьи 306.2 БК РФ санкции налагаются за правонарушения, составы которых сформулированы в статьях 306.4 - 306.8 БК РФ.

\section{Выводы}

Буквальный анализ формулировок объективной стороны составов правонарушений, содержащихся в КоАП РФ и БК РФ, позволяет сделать вывод о том, что они, по сути, тождественны, но, при этом законодатель предусматривает различные санкции: меры административного наказания в виде административного штрафа и дисквалификации и бюджетные меры принуждения.

Сравнительный анализ правовых предписаний, содержащих составы правонарушений в финансовой сфере, и изложенных в КоАП РФ и БК РФ, обозначил проблему отсутствия корреляции между составами административных и бюджетных правонарушений. Субъектами административных правонарушений, содержащихся в ст.ст. 15.14. - 15.15.3 КоАП РФ, выступают юридические и должностные лица. Субъектами правонарушений в бюджетной сфере в соответствии с нормами, предусмотренными в статьях 306.4 306.8 БК РФ являются финансовые органы. Правовая специфика данного понятия заключается в том, что оно носит синкретический характер, так как включает как органы исполнительной власти, обладающих статусом юридических лиц, так и собственно должностных лиц, подпадающих под признаки, предусмотренных ст. 2.4 КоАП РФ.

Должностные лица и юридические лица являются субъектами административных правонарушений, следовательно, составы правонарушений, предусмотренные статьями 306.4 - 306.8 БК РФ, по сути, дублируют составы правонарушений, изложенные в статьях 15.14. - 15.15.3. КоАП РФ, но при этом содержат специфические бюджетные меры государственного принуждения, которых нет в перечне мер административных наказаний, предусмотренных КоАП РФ.

На основании изложенного, предлагается провести корреляцию составов правонарушений, применять к правонарушителям норм БК РФ нормы Кодекса РФ об административных правонарушениях, но при этом в качестве дополнительных санкций применять специальные бюджетные меры государственного принуждения, изложенные в главе 30 БК РФ. Предлагается дополнить санкции соответствующих норм КоАП РФ отсылками к соответствующим нормам БК РФ, содержащим специфические бюджетные меры принуждения, указанные в главе 30 БК РФ.

\section{Библиография:}

1. Кодекс Российской Федерации об административных правонарушениях от 30.12.2001 N 195-Ф3 (ред. от 05.05.2014) (с изм. и доп., вступ. в силу с 22.06.2014) // «Собрание законодательства РФ», 07.01.2002, N 1 (ч. 1), ст. 1. 
2. Бюджетный кодекс Российской Федерации от 31.07.1998 N 145-Ф3 (ред. от 28.12.2013, с изм. от 03.02.2014) (с изм. и доп., вступ. в силу с 01.01.2014) // «Собрание законодательства РФ», 03.08.1998, N 31, ст. 3823.

3. Федеральный закон от 23 июля 2013 г. № 252 - Ф3 «О внесении изменений в Бюджетный кодекс Российской Федерации и отдельные законодательные акты Российской Федерации» // РГ. N 172. 07.08.2013.

4. Административное право Российской Федерации / отв. редактор Л.Л. Попов. Учебник для бакалавров. М., 2014.568 С.

5. Бахрах Д.Н. Административное право России. Учебник. 5-е издание. М., 2010. 607 с.

6. Кардашевский В.В. К вопросу о понятии «административная юрисдикция» // Административная юрисдикция: материалы Всероссийской научно-практической конференции / Под ред. зав. кафедрой административного права ВГНА Минфина России, доктора юридических наук, профессора М.А. Лапиной. М., ВГНА Минфина. 2012 . С. 34 - 36.

7. Козлов Ю.М. Административное право. Учебник. М., 2005. 554 с.

8. Лапина М.А. Современные подходы к определению содержания и структуры института административной юрисдикции в системе административного процесса // Административная юрисдикция: материалы Всероссийской научно-практической конференции / Под ред. зав. кафедрой административного права ВГНА Минфина России, доктора юридических наук, профессора М.А. Лапиной. М., ВГНА Минфина. 2012. С. 11 - 21.

9. Отчёт по НИР «Актуальные вопросы совершенствования правового регулирования в области бюджетных отношений» (научный руководитель, д.ю.н., профессор А.А. Фатьянов). М., Финуниверситет, 2013. // Текст отчёта размещён на информационно-образовательном портале Финуниверситета.

10. Панов А.Б. О некоторых вопросах административной юрисдикции // Административная юрисдикция: материалы Всероссийской научно-практической конференции / Под ред. зав. кафедрой административного права ВГНА Минфина России, доктора юридических наук, профессора М.А. Лапиной. М., ВГНА Минфина. 2012. С. 27 - 31.

11. Шергин А.П. Размышления об административной юрисдикции // Административная юрисдикция: материалы Всероссийской научно-практической конференции / Под ред. зав. кафедрой административного права ВГНА Минфина России, доктора юридических наук, профессора М.А. Лапиной. М., ВГНА Минфина. 2012 . С. 21 - 27.

12. Агапов А.Б. Публичное принуждение или общественная санация // Административное и муниципальное право. 2013. - 7. - C. 743 - 752. DOI: 10.7256/1999-2807.2013.7.9037.

13. Лапина М.А. Концептуальные вопросы развития административно-юрисдикционного законодательства в области финансов, налогов и сборов, страхования, рынка ценных бумаг // Административное и муниципальное право. - 2014. - 8. - C. 843 - 856. DOI: 10.7256/1999-2807.2014.8.12396.

\section{References (transliterated):}

1. Kodeks Rossiiskoi Federatsii ob administrativnykh pravonarusheniyakh ot 30.12.2001 N 195-FZ (red. ot 05.05.2014) (s izm. i dop., vstup. v silu s 22.06.2014) // «Sobranie zakonodatel'stva RF», 07.01.2002, N 1 (ch. 1), st. 1.

2. Byudzhetnyi kodeks Rossiiskoi Federatsii ot 31.07.1998 N 145-FZ (red. ot 28.12.2013, s izm. ot 03.02.2014) (s izm. i dop., vstup. v silu s 01.01.2014) // «Sobranie zakonodatel'stva RF», 03.08.1998, N 31, st. 3823.

3. Federal'nyi zakon ot 23 iyulya 2013 g. № 252 - FZ «0 vnesenii izmenenii v Byudzhetnyi kodeks Rossiiskoi Federatsii i otdel'nye zakonodatel'nye akty Rossiiskoi Federatsii» // RG. N 172. 07.08.2013.

4. Administrativnoe pravo Rossiiskoi Federatsii / otv. redaktor L.L. Popov. Uchebnik dlya bakalavrov. M., 2014. 568 S.

5. Bakhrakh D.N. Administrativnoe pravo Rossii. Uchebnik. 5-e izdanie. M., 2010.607 s.

6. Kardashevskii V.V. K voprosu o ponyatii «administrativnaya yurisdiktsiya» // Administrativnaya yurisdiktsiya: materialy Vserossiiskoi nauchno-prakticheskoi konferentsii / Pod red. zav. kafedroi administrativnogo prava VGNA Minfina Rossii, doktora yuridicheskikh nauk, professora M.A. Lapinoi. M., VGNA Minfina. 2012. S. 34 - 36.

7. Kozlov Yu.M. Administrativnoe pravo. Uchebnik. M., 2005. 554 s.

8. Lapina M.A. Sovremennye podkhody k opredeleniyu soderzhaniya i struktury instituta administrativnoi yurisdiktsii v sisteme administrativnogo protsessa // Administrativnaya yurisdiktsiya: materialy Vserossiiskoi nauchno-prakticheskoi konferentsii / Pod red. zav. kafedroi administrativnogo prava VGNA Minfina Rossii, doktora yuridicheskikh nauk, professora M.A. Lapinoi. M., VGNA Minfina. 2012. S. 11 - 21.

9. Otchet po NIR «Aktual'nye voprosy sovershenstvovaniya pravovogo regulirovaniya v oblasti byudzhetnykh otnoshenii» (nauchnyi rukovoditel', d.yu.n., professor A.A. Fat'yanov). M., Finuniversitet, 2013. // Tekst otcheta razmeshchen na informatsionno-obrazovatel'nom portale Finuniversiteta.

10. Panov A.B. O nekotorykh voprosakh administrativnoi yurisdiktsii // Administrativnaya yurisdiktsiya: materialy Vserossiiskoi nauchno-prakticheskoi konferentsii / Pod red. zav. kafedroi administrativnogo prava VGNA Minfina Rossii, doktora yuridicheskikh nauk, professora M.A. Lapinoi. M., VGNA Minfina. 2012. S. 27 - 31.

11. Shergin A.P. Razmyshleniya ob administrativnoi yurisdiktsii // Administrativnaya yurisdiktsiya: materialy Vserossiiskoi nauchno-prakticheskoi konferentsii / Pod red. zav. kafedroi administrativnogo prava VGNA Minfina Rossii, doktora yuridicheskikh nauk, professora M.A. Lapinoi. M., VGNA Minfina. 2012. S. 21 - 27.

12. Agapov A.B. Publichnoe prinuzhdenie ili obshchestvennaya sanatsiya // Administrativnoe i munitsipal'noe pravo. - 2013. 7. - C. 743 - 752. DOI: 10.7256/1999-2807.2013.7.9037.

13. Lapina M.A. Kontseptual'nye voprosy razvitiya administrativno-yurisdiktsionnogo zakonodatel'stva v oblasti finansov, nalogov i sborov, strakhovaniya, rynka tsennykh bumag // Administrativnoe i munitsipal'noe pravo. - 2014. - 8. - C. 843 856. DOI: 10.7256/1999-2807.2014.8.12396. 